\title{
SPONGIOUS FILLERS BASED ON COLLAGEN - HYDROXYAPATITE - EUGENOL ACETATE WITH THERAPEUTIC POTENTIAL IN BONE CANCER
}

\author{
ALINA F. VLADU ${ }^{1}$, STEFANIA MARIN ${ }^{2,3}$, IONELA A. NEACŞU ${ }^{1}$, ROXANA D. TRUŞCĂ ${ }^{1}$, \\ MĂDĂLINA G. ALBU KAYA ${ }^{2}$, DURMUS A. KAYA ${ }^{4}$, ANA-MARIA POPA ${ }^{5}$, CĂTĂLINA \\ POIANA ${ }^{6}$, IOAN CRISTESCU ${ }^{6} *$, CRISTINA ORLOV ${ }^{5}$, DENISA FICAI ${ }^{1}$, ANTON FICAI $^{1,7}$, \\ DENISA I. UDEANU ${ }^{6}$, BRUNO ȘTEFAN VELESCU ${ }^{6}$, TAXIARCHIS KONSTANTINOS \\ NIKOLOUZAKIS ${ }^{8}$, LEONID GUREVICH $^{9}$, ANDREY N. KUSKOV ${ }^{10,11}$, CORNELIA NIȚIPIR $^{5,6}$ \\ ${ }^{1}$ University Politehnica of Bucharest, Faculty of Applied Chemistry and Materials Science, 060042, Bucharest, Romania \\ ${ }^{2}$ Collagen Department, Division Leather and Footwear Research Institute, National Research and Development Institute for \\ Textile and Leather, 031215 Bucharest, Romania \\ ${ }^{3}$ Center of Surface Science and Nanotechnology, University Politehnica of Bucharest, 060042 Bucharest, Romania \\ ${ }^{4}$ Department of Field Crops, Agriculture Faculty, Hatay Mustafa Kemal University, Antakya, Turkey \\ ${ }^{5}$ Clinic of Medical Oncology, Elias University Emergency Hospital, Bucharest, Romania \\ 6 "Carol Davila" University of Medicine and Pharmacy, Bucharest, Romania \\ ${ }^{7}$ Academy of Romanian Scientists, Bucharest, Romania \\ ${ }^{8}$ Laboratory of Toxicology, University of Crete, Voutes, Heraklion, Crete, Greece \\ ${ }^{9}$ Department of Materials \& Production, Aalborg University, Skjernvej 4A, Aalborg, Denmark \\ ${ }^{10}$ Department of Technology of Chemical Pharmaceutical and Cosmetic Products, D. Mendeleev University of Chemical \\ Technology of Russia, Moscow, Russian Federation \\ ${ }^{11}$ Department "Chembiotech", Moscow Polytechnic University, Moscow, Russian Federation
}

*corresponding author: ioancristescu@yahoo.com

\begin{abstract}
The aim of this study was to develop and characterize composite materials based on collagen, hydroxyapatite and eugenol acetate as new filler biomaterial for the reconstruction of the tissue damage arising after the resection in case of bone cancer. Composite gels consisting of collagen and hydroxyapatite in different proportions (Coll:HAp - 100:0; 70:30; 40:60 - w/w) and 0.5\% eugenol acetate were lyophilized and spongious fillers were obtained. The fillers were characterized by water absorption, enzymatic degradation and examined by optical and scanning electron microscopy, EDS, FT-IR spectroscopy while eugenol acetate release from the compositions was also studied. The results showed that the filler with optimal composition (Coll-HAp - 40:60 w/w) completely degrade over about 48 hours, the release capacity being longer during the 144 hours. The complex results obtained from physicalchemical, morphological and eugenol acetate release profile evaluation for the designed composite materials based on collagen and hydroxyapatite testify these formulations as drug delivery systems with potential applications as fillers in orthopaedic field in bone cancer.
\end{abstract}

\section{Rezumat}

Studiul a avut ca obiectiv dezvoltarea şi caracterizarea unor materiale compozite pe bază de colagen, hidroxiapatită și acetat de eugenol ca biomateriale de umplere în reconstrucția tisulară după rezecția în cancerul osos. Geluri compozite care conțin colagen și hidroxiapatită în diferite proporții (Coll:HAp - 100:0; 70:30; 40:60 - g/g) și 0,5\% acetat de eugenol au fost liofilizate și s-au obținut materiale spongioase pentru umplere. Aceste materiale au fost caracterizate din punct de vedere a capacității de absorbție a apei și a degradării enzimatice, examinate prin microscopie optică și electronică, EDS, spectroscopie FT-IR și a fost investigată cedarea acetatului de eugenol din compozite. Rezultatele obținute au demonstrat că materialele de umplere cu compoziţie optimă (Coll-HAp - 40:60 g/g) se degradează complet după 48 de ore, iar capacitatea de eliberare depășește 144 de ore. Rezultatele complexe obținute în urma evaluărilor morfologice, fizico-chimice și a profilului de cedare al acetatului de eugenol privind materialele compozite pe bază de colagen și hidroxiapatită susțin potențialul acestor formulări ca sisteme de cedare de umplere în ortopedia cancerului osos.

Keywords: collagen, hydroxyapatite, eugenol acetate, bone cancer, fillers

\section{Introduction}

In recent years, the need for novel bone grafts has increased considerably due to the growing incidence of congenital and non-congenital diseases as well as fractures. Bone cancer has become more and more common among young people, and the need for bone grafting is high. In this way, it is desirable to 
find the best materials able of replacing autografts and allografts, especially if the size of the bone defect exceeds their availability [1]. The use of synthetic grafts brings important advantages over allografts, autografts and xenografts: the possibility of large-scaled production of synthetic grafts; their higher safety without the risk of immune and disease related complications; lower invasiveness by avoiding secondary surgical intervention required for autologous bone transplantation and accompanying bone damage and pain [2].

Bones are primarily composed of collagen fibres (mainly type-I) reinforced by hydroxyapatite. When used in implants, both materials have been shown to be osteoconductive, i.e. capable of supporting bone growth, due to their compositional and structural similarity with the natural bone [3, 4]. The role of these components is very important. It is believed that the hydroxyapatite-containing mineral phase provides resistance and rigidity, while the organic matrix brings the bone strength, traction and flexibility. Collagen and hydroxyapatite in a composite material assume the same role as in natural tissue $[5,6]$.

Both type-I collagen and hydroxyapatite have been shown to stimulate differentiation of osteoblasts, but when combined they promote osteogenesis [7]. Such composites also behave in a superior mechanical manner compared to the individual components. The ductile features of collagen help to increase the weak resistance to fracture of hydroxyapatite $[8,9]$.

Cancers represent a major health problem. Despite early diagnostic and follow-up using recently available advanced techniques, such as video contact endoscopy [10] and various staining and imaging methods [11], most patients are still diagnosed in the advanced stages of disease. Surgery, radiotherapy and chemotherapy are used in order to achieve better survival rate. A crucial role in establishing the prognosis for the patient is attributed to the surgeon's ability to respect the tumour with disease-free margins [12]. However, the development of the disease may also be influenced by microscopic changes, that is why tests like ELISA assays or flow cytometry are necessary [13].

There are two possible strategies in cancer treatment. Either surgery is performed first to remove tumoural tissue as completely as possible, followed by chemotherapy or radiotherapy, to destroy any cancerous cells left behind by the resection, or the intervention is performed in the opposite direction chemo or radiotherapy is applied first, followed by surgical removal of the tumoural tissue. In both scenarios, it is necessary to reconstruct the bone damage arising after the resection [14]. Composite systems based on collagen and hydroxylapatite are most appropriate for this purpose, considering the similarity with the composition of the natural bone. However, simple collagen-hydroxyapatite composition does not suppress the cancer cells, hence adding of various antitumor substances can improve the overall therapy efficacy. Further improvement can be achieved by applying antitumor agents in the form of highly effective nano-scaled drug delivery systems, which can provide anticancer drug with good bioavailability, biodistribution, prolonged controlled release, and low side toxicity [15-18]. Such carriers also increase water compatibility of hydrophobic biologically active substances which is important for their successful application [19].

Eugenol is the main phenolic component of the essential oil extracted from the Syzygium aromaticum L. flower. Recently, additional pharmacological properties of this compound have been demonstrated, including antiseptic, analgesic, potent bactericidal and fungicidal activity, anticarcinogenic, anti-allergic, antioxidant and anti-inflammatory effects [20]. Essential oils are chemically unstable in the presence of light, air, moisture, and high temperatures that can cause the rapid evaporation and degradation of some active compounds. Moreover, eugenol has poor water solubility due to its lipophilic nature. These characteristics limit its application in pharmaceutical formulations. One of possible ways to overcome these limits is to use a dedicated drug delivery system, for example polymeric nanoparticles, to solubilize hydrophobic agent and increase its efficiency [21]. Another way is to use eugenol in the acetate form which leads to improved physical and chemical stability, by adding acetate functional groups in its structure increasing the therapeutic efficacy [22].

Eugenol acetate has excellent anti-tumoral properties and, furthermore, is a natural product with low systemic toxicity [23]. A major advantage of eugenol acetate is its hydrophobicity, which ensures a local release of the substance. This avoids systemic toxicity and promotes a more pronounced local effect [24, 25]. Eugenol acetate shows activity against various types of cancer cells. The molecular mechanism of eugenolinduced apoptosis in melanoma, osteosarcoma, leukaemia, gastric cancer and mast cells has been well studied [26, 27].

Apart from its proven cytotoxic effect, the possibility of this compound to induce immunogenic activity has to be taken into consideration. When apoptosis in the tumoural cells occurs, several antigens are released, making the tumour more immunogenic. This process has been described for other chemical compounds, but in the case of eugenol further research is needed [28, 29].

It is estimated that more than $80 \%$ of the world's population cannot afford the costs of modern medicine. In addition, current cancer therapies have minimal efficacy and show side toxicity that is hard to bear in most cases. It is therefore advantageous, to increase the use of natural products not only to prevent cancer, but also to treat it. Due to pharmaceutical safety, these agents can be used alone or as adjuvants of common 
FARMACIA, 2020, Vol. 68, 2

chemotherapeutic agents to increase the therapeutic effect and minimize toxicity [30, 31].

Collagen, hydroxyapatite and eugenol acetate composites seem to have the qualities required for use in the treatment of bone cancer. Therefore, the aim of this study was to develop and characterize composite materials based on collagen, hydroxyapatite and eugenol acetate as new bone filler biomaterial for cancer treatment.

\section{Materials and Methods}

\section{Materials}

Type I collagen (Coll) gel was extracted from bovine skin according to the method developed in INCDTP Leather and Footwear Research Institute, Collagen Research Department [31], with a collagen concentration of $2.37 \%(\mathrm{w} / \mathrm{v})$. Hydroxyapatite (HAp), eugenol acetate (EUG) and collagenase used for enzymatic degradation studies were purchased from Sigma-Aldrich (Munich, Germany). Sodium hydroxide from Merck (Darmstadt, Germany) was of analytical grade and the water was distilled.

Preparation of collagen-hydroxyapatite fillers

The concentration of collagen gel was adjusted to $1 \%$ (w/v) and $7.2-7.4 \mathrm{pH}$ (the $\mathrm{pH}$ of the physiological medium) with $1 \mathrm{M}$ sodium hydroxide solution. Subsequently, hydroxyapatite was dispersed in collagen gel in various proportions (Coll:HAp - 100:0, 70:30, 40:60 - w/w) thus obtaining 3 control samples without drug. After that, $0.5 \%$ eugenol acetate was added to the same compositions so that 3 additional samples containing active substance were prepared. All six samples were further cross-linked using $0.025 \%$ glutaraldehyde (GA) as shown in Table I.

Table I

Composition of obtained Coll-HAp fillers

\begin{tabular}{|c|c|c|c|c|}
\hline $\begin{array}{c}\text { Sample } \\
\text { name }\end{array}$ & Coll, \% & НАр, \% & EUG, \% & GA, \% \\
\hline S1 & 100 & - & - & \multirow{6}{*}{$0.025^{*}$} \\
\hline S2 & 70 & 30 & - & \\
\hline S3 & 40 & 60 & - & \\
\hline S4 & 100 & - & 0.5 & \\
\hline S5 & 70 & 30 & 0.5 & \\
\hline S6 & 40 & 60 & 0.5 & \\
\hline
\end{tabular}

*in regard to collagen mass

After preparation, all the formulations were lyophilized for 48 hours using a Delta 2-24 LSC Christ lyophilizer (Germany) as previously described [32].

Water Absorption

To test the water absorption capacities, dried lyophilized samples were weighed, immersed in water at $36^{\circ} \mathrm{C}$ and then weighed again at specified time intervals. The absorption capacity was defined as (Equation (1)):
Water absorption $=(\mathrm{Wt}-\mathrm{Wd}) / \mathrm{Wd} \times 100,[\%]$ (1)

where Wt represents the weight of a sample immersed for the time $t$ and $\mathrm{Wd}$ is the dry weight. All samples were analysed in triplicate for better accuracy [20]. Enzymatic Degradation

Enzymatic degradation of Coll-HAp fillers was accomplished by immersing pieces of the hydrated samples in a collagenase solution and monitoring their degradation over time. To monitor the weight loss, samples were removed from the collagenase solution at specified time intervals and weighed. The weight loss was calculated as follows (Equation (2)):

Weight loss $=(\mathrm{Wi}-\mathrm{Wt}) / \mathrm{Wt} \times 100,[\%]$

where Wi represents the initial weight and $\mathrm{Wt}$ is the weight of the sample after the time interval $t$ [21].

Optical microscopy

Optical microscopy images of Coll-HAp fillers were obtained for lyophilized samples, catted in $1 \mathrm{~cm}^{2}$ pieces, were obtained using a Leica S8AP0 stereomicroscope (Tokyo, Japan) with a 10x - 160x magnification range in incident light.

Scanning electron microscopy

In order to obtain scanning electron microscopy images of Coll-HAp fillers, a Quanta Inspect F SEM apparatus equipped with an EDS (X-ray Dispersive Spectrometry) detector was used. No additional preparation steps were necessary, all the samples being analysed in cross-section.

\section{FT-IR}

Fourier Transform Infrared Spectroscopy (FT-IR) was performed on Coll-HAp fillers using a Nicolet iS 50 FT-IR spectrometer equipped with a DTGS detector and a diamond ATR unit. All spectra were recorded on lyophilized samples, the spectral resolution being $4 \mathrm{~cm}^{-1}$ over the $4000-400 \mathrm{~cm}^{-1}$ range. To avoid any additional smoothing and atmospheric corrections, the spectra were recorded by co-adding 64 scans while background was recorded before each sample.

High Performance Liquid Chromatography

High Performance Liquid Chromatography (HPLC) was performed with the Agilent 1260 Infinity Quaternary LC equipment with a 600bar quaternary pump, a thermostated column compartment and a diode-array detector (UV) in order to quantify the eugenol acetate release,

\section{Results and Discussion}

The obtained composite fillers were evaluated in terms of water absorption capacity during $48 \mathrm{~h}$ exposure to water and the results obtained are presented in Figure 1. 


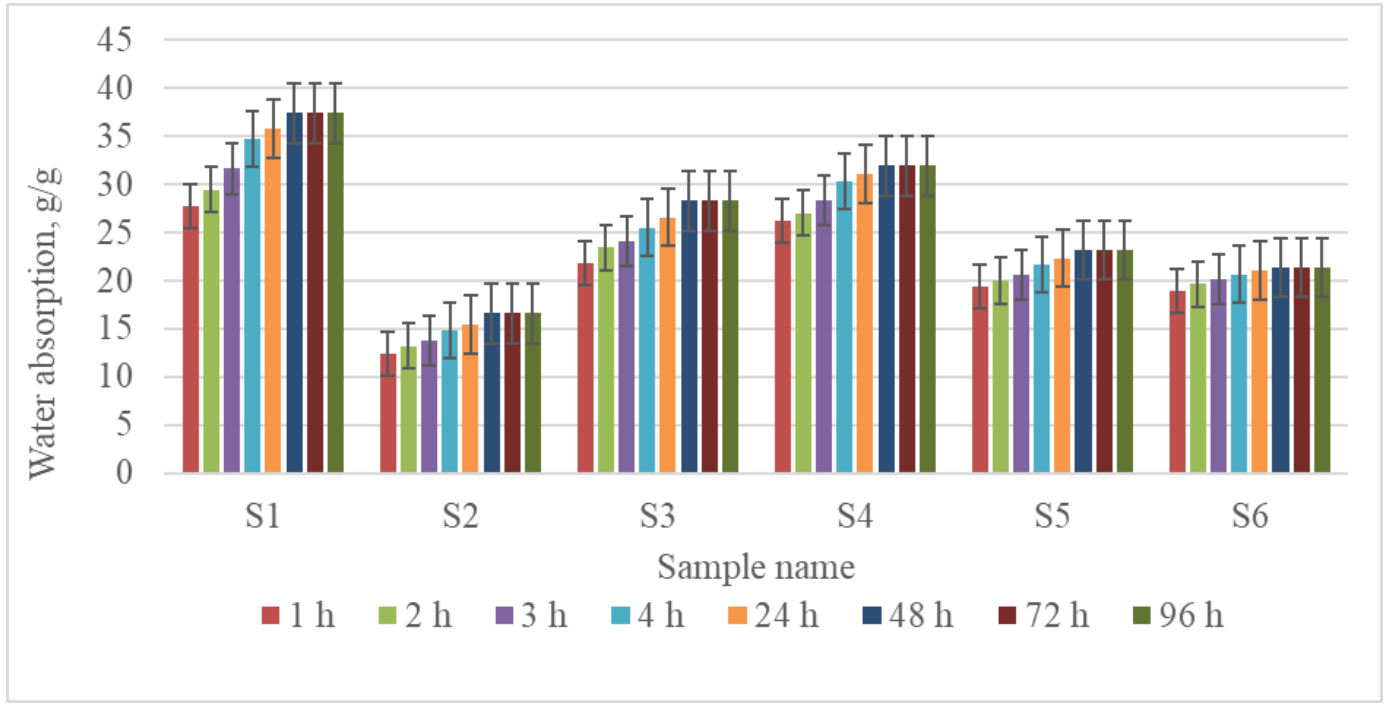

Figure 1.

Evaluation of water uptake of the samples on $1-96 \mathrm{~h}$

Figure 1 show that all the 6 samples absorbed high amount of water within first hour and then slowly continue to absorb water until 48 hours until the equilibrium was reached. Hydroxyapatite induces some morphological changes - decreasing the amount of absorbed water in the samples containing HAp, as the samples become more compact. Comparing the samples containing eugenol acetate (S4, S5, S6) with those consisting only of collagen and hydroxyapatite (S1, S2, S3), there is a decrease in the amount of water absorbed by samples containing eugenol acetate due to its hydrophobic character which impedes the penetration of water. For example, water absorption for the sample containing $100 \%$ collagen is $37 \%$ after 48 hours, while for the $100 \%$ collagen sample containing eugenol acetate it is around $32 \%$.

Subsequently, the samples degradation was studied using a solution of collagenase, a collagen-degrading enzyme. The weight loss for all the samples is presented in Figure 2.

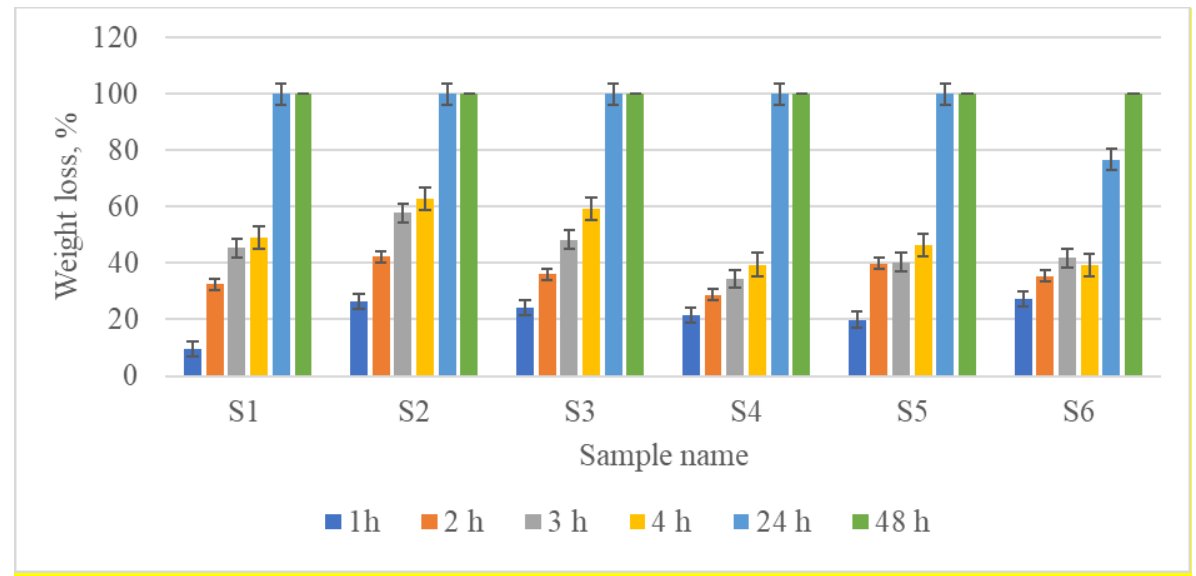

Figure 2.

Weight loss for Coll-HAp fillers in collagenase solution, during 48 hours

It can be seen that there is an increase in lost mass over the 48 hours for all six samples. Over 24 hours complete sample degradation took place, except sample S6, which suffers a $77 \%$ loss on 24 hours and degrades completely only after 48 hours. The rate of mass loss within the first 4 hours is slightly increased in the case of samples containing hydroxyapatite, most likely due to the release of hydroxyapatite which is happening in the same time with the enzymatic degradation of collagen fibres. Furthermore, the samples with eugenol acetate degrade slower in the first 4 hours, in line with the results on water absorption.

Figure 3 shows optical micrographs for all the samples studied. The collagen specific porous structure can be observed on these images. No large agglomerates are visible, indicating that samples were sufficiently homogenized and no impurities were present. The presence of eugenol acetate which is distributed in the collagen matrix does not influence the appearance of the scaffold noticeably. The porous structure with 
micro-scaled pores can be seen, and the collagen fibres give a "spider web" appearance of the scaffold.

The obtained samples were also analysed using scanning electron microscopy to highlight the morphology of the surface of the obtained composite fillers, the distribution of hydroxyapatite in the polymer matrix, the assessment of the appearance and the size of the pores. Figure 4 illustrates scanning electron microscopy images at 100x magnification corresponding to the six collagen-based composite systems, with or without nanohydroxyapatite and eugenol acetate. From the analysis of these images the structure of the collagen can be revealed, exhibiting interconnected pores ranging from $100-300 \mu \mathrm{m}$ can also be observed from microphotographs.
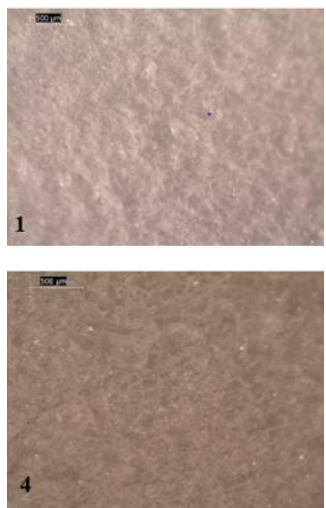
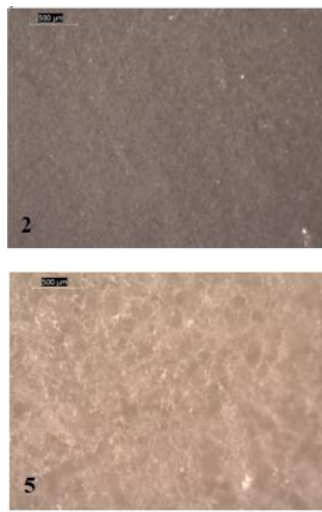

Figure 3.

Optical microscopy images of: 1) Collagen 100\%, 2) Collagen 70\%:Hydroxyapatite 30\%, 3) Collagen 40\%: Hydroxyapatite 60\%, 4) Collagen 100\% - eugenol acetate, 5) Collagen 70\%:Hydroxyapatite 30\% - eugenol acetate, 6) Collagen $40 \% /$ Hydroxyapatite $60 \%$ - eugenol acetate samples
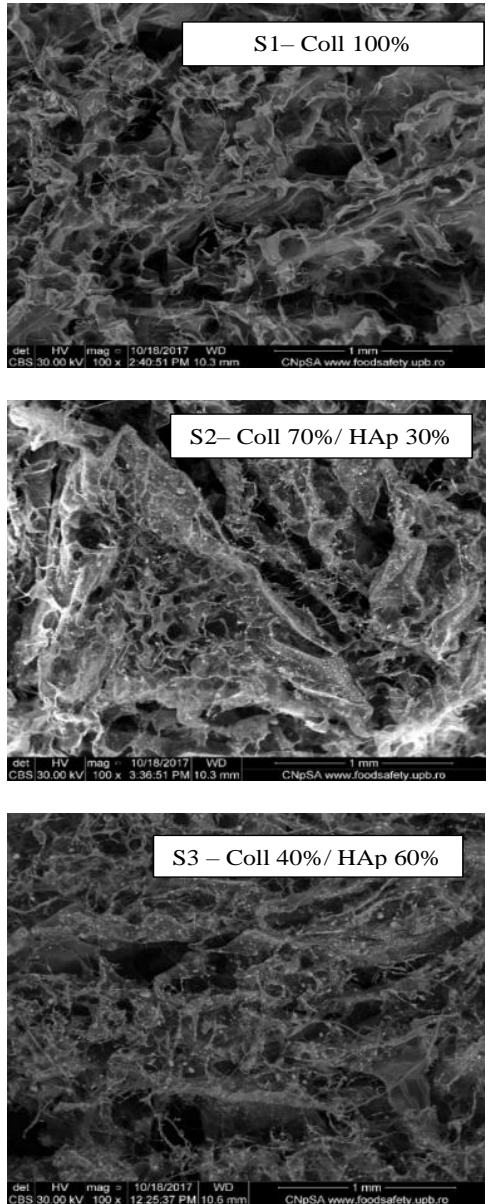
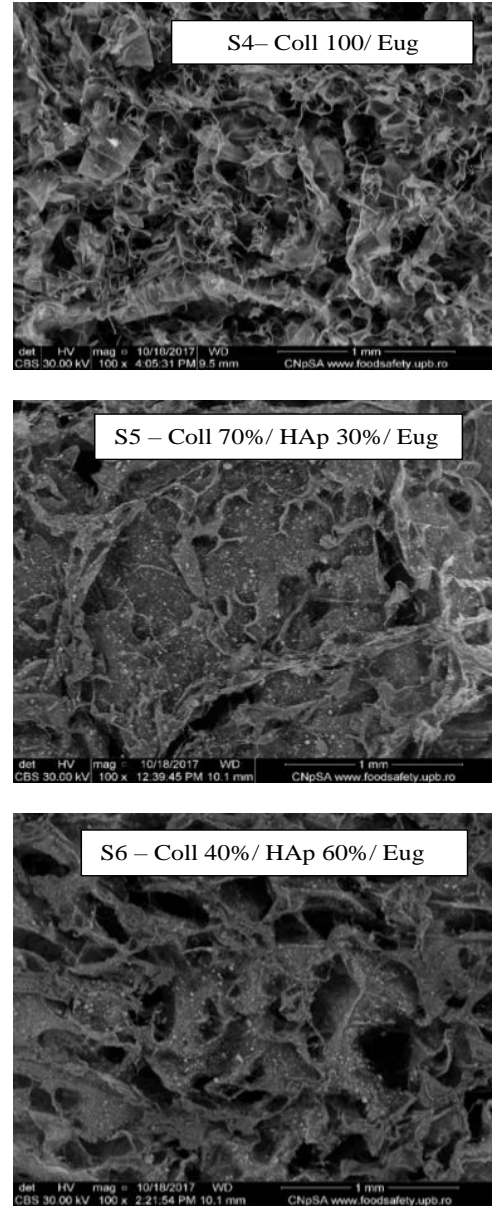

Figure 4.

Scanning electron microscopy images for all fillers, 100X 
In the case of samples S2, S3, S5 and S6, particles of hydroxyapatite can be observed. The particle exhibits a fairly uniform distribution in the collagen matrix, which is evidence of good homogeneity between the mineral and organic phases. There is no visible influence given by eugenol acetate on the morphology of Coll-HAp fillers. This fact is in accordance with the literature especially because of the low content of Eugenol Acetate $(0.5 \%)$.

By coupling the scanning electron microscopy with $\mathrm{X}$-ray energy dispersion analysis, the spectrum that

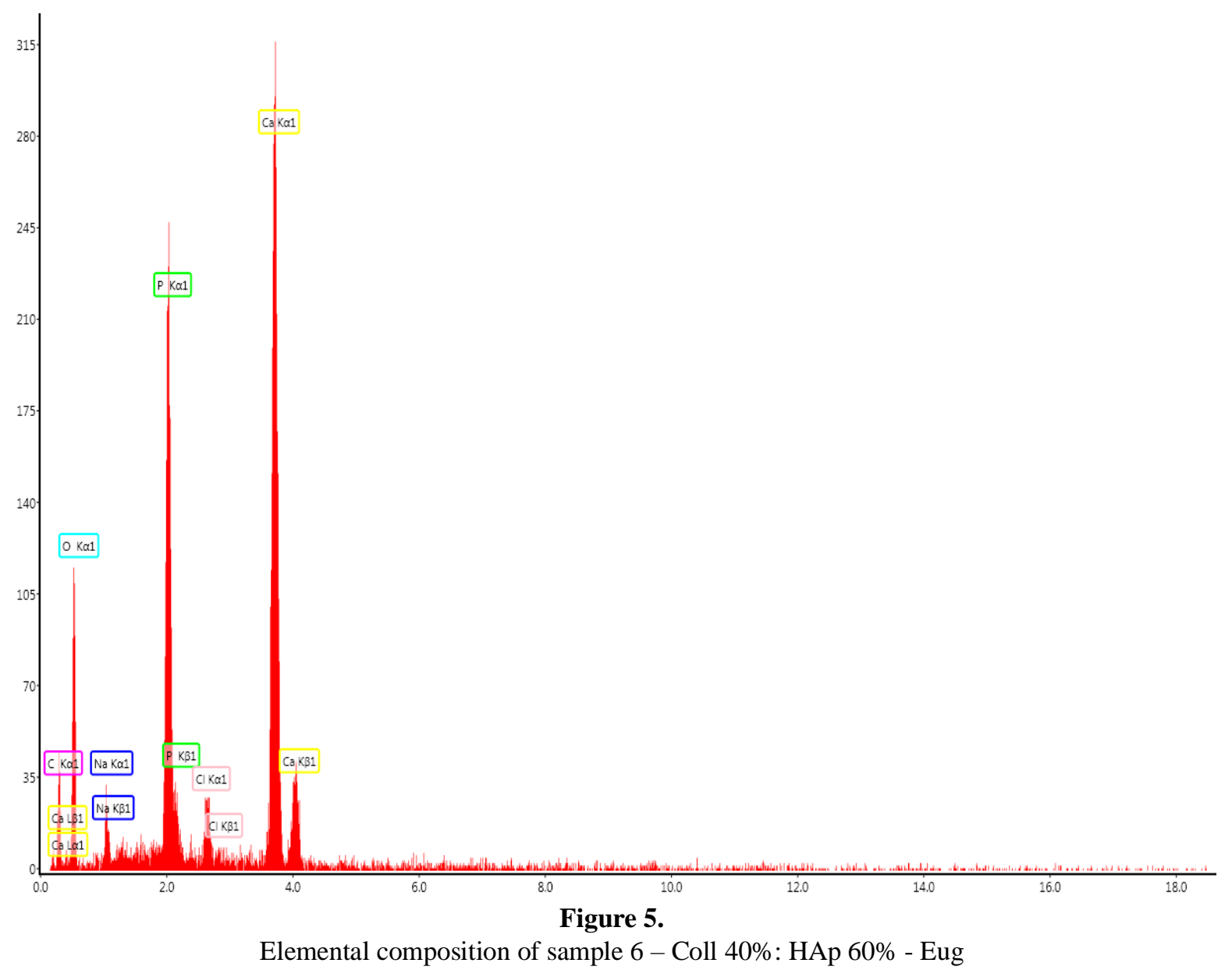

FT-IR spectrum shown in Figure 6 confirms the presence of chemical bonds characteristic for the composite materials based on collagen and hydroxyapatite. The collagen-specific absorption bands at $1638 \mathrm{~cm}^{-1}\left(v_{C=O}\right.$ amide I - $\alpha$ helix), $1547 \mathrm{~cm}^{-1}$ (amide II), $1451 \mathrm{~cm}^{-1}\left(\delta_{N H}\right), 1239 \mathrm{~cm}^{-1}$ (amide III) $1401 \mathrm{~cm}^{-1}$ $\left(v_{\text {COO- }}\right), 3080 \mathrm{~cm}^{-1}\left(v_{\mathrm{CH}_{2}}\right.$ symmetric), $2922 \mathrm{~cm}^{-1}$ ( $v_{\mathrm{CH} 2}$ symmetric), $2851 \mathrm{~cm}^{-1}\left(v_{\mathrm{CH} 2}\right.$ asymmetric)can be easily identified in the spectrum. Also, the presence of hydroxyapatite is confirmed by the very intense bands at $560 \mathrm{~cm}^{-1}$ and $600 \mathrm{~cm}^{-1}\left(v_{4}\left(\mathrm{PO}_{4}^{3-}\right)\right)$ symmetric and asymmetric and from $963 \mathrm{~cm}^{-1}\left(\mathrm{HPO}_{4}^{2-}\right), 1027$ $\mathrm{cm}^{-1}\left(v_{3}\left(\mathrm{PO}_{4}^{3-}\right)\right)$, as well as that of the carbonate group described the elemental composition of the samples was obtained. Using this technique, elements such as $\mathrm{Ca}, \mathrm{P}, \mathrm{Na}, \mathrm{Cl}, \mathrm{O}$ and $\mathrm{C}$ (Figure 5) were identified. Thus, we can state that the presence of calcium, phosphorus and oxygen indicates can be connected with the presence of hydroxyapatite in the compositions. There are also noticeable amounts of sodium and chlorine most likely from $\mathrm{NaCl}$ which is used in the collagen production technique and is not toxic at these concentrations.
Figure 5. at $875 \mathrm{~cm}^{-1}\left(v_{2}\left(\mathrm{CO}_{3}^{2-}\right)\right)$. There is also overlapping of some characteristic bands, common to both organic and inorganic groups: carbonate - collagen $v_{3}\left(\mathrm{CO}_{3}^{2-}\right)$ from $1400-1580 \mathrm{~cm}^{-1}$ and $1350-1550 \mathrm{~cm}^{-1}$ domain) or hydroxyapatite - collagen from $3000-3600 \mathrm{~cm}^{-1}$ which corresponds to hydroxyl associated by hydrogen bonds of hydroxyapatite, collagen and water. The spectra of samples 4-6 (containing eugenol acetate) additionally show new bands characteristic for eugenol acetate. They are visible at $1765 \mathrm{~cm}^{-1}$ corresponding to the carbonyl group of the ester linked to the aromatic ring at $1509 \mathrm{~cm}^{-1}, 1197 \mathrm{~cm}^{-1}$, and 1121 $\mathrm{cm}^{-1}$. 


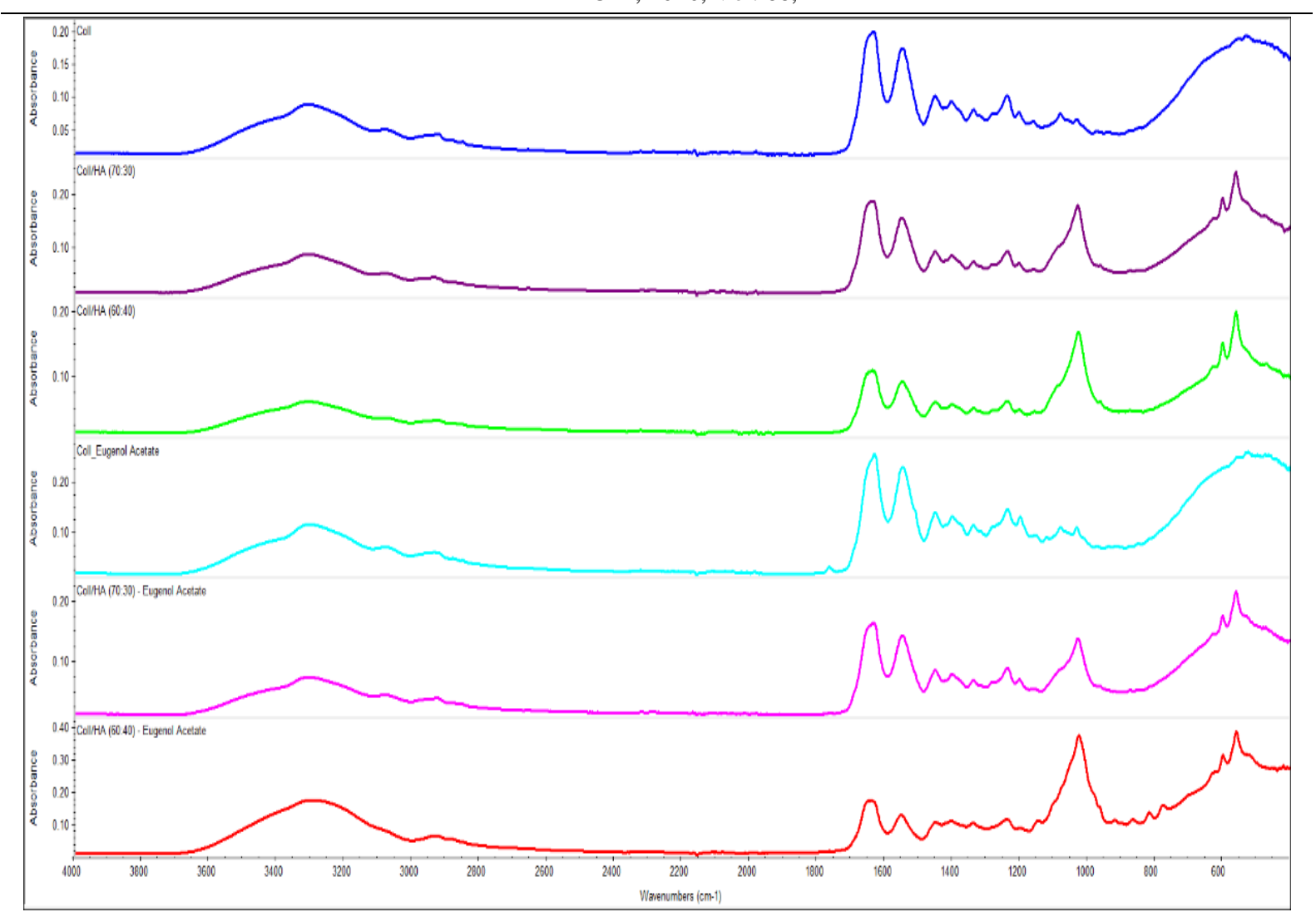

Figure 6.

FT-IR Spectra for Coll-HAp fillers

To assess the stability of the fillers and to determine the kinetics of eugenol acetate release, the samples were immersed in saline phosphate buffer (PBS). Aliquots of the were taken at 1,2, 4, 8, 21 and 144 hours to determine the content of eugenol acetate.
The aliquots were analysed using High Performance Liquid Chromatography (HPLC) obtain the release profile of Eugenol Acetate from the compositions. The results obtained are presented in Figure 7.

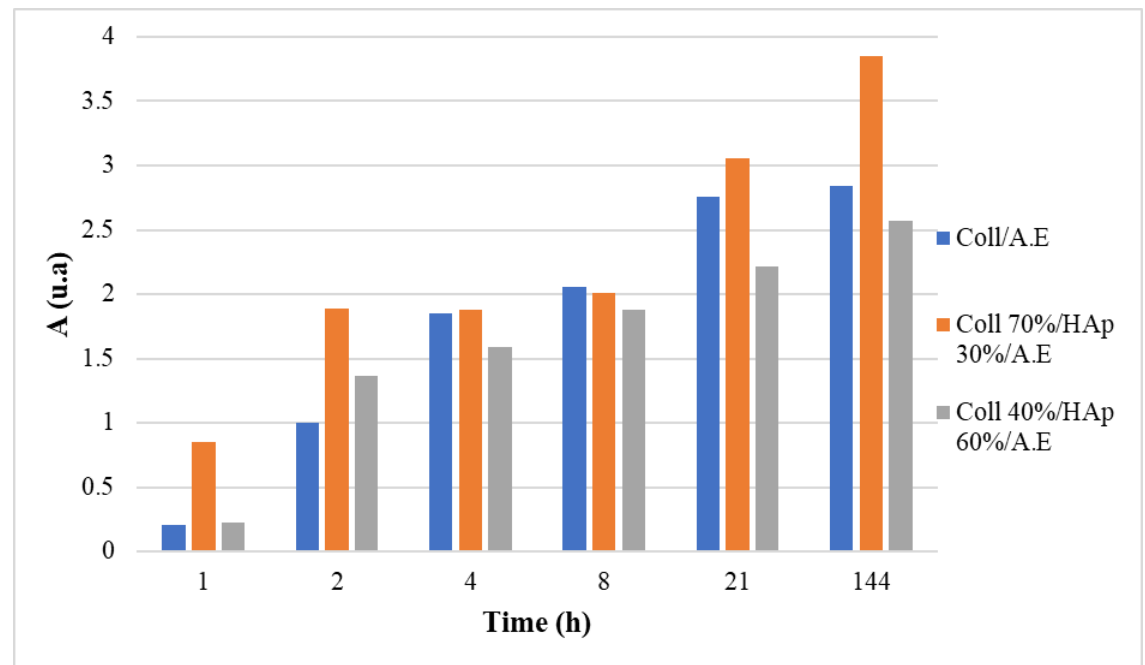

Figure 7.

Release kinetics of eugenol acetate from samples S4, S5 and S6

As it can be seen from Figure 7, the concentration of eugenol acetate released from all the composite systems has an increasing trend over time, even if there are several deviations. For sample S5 - Coll
70\%/HAp 30\%/eugenol acetate, the release is more pronounced, even if the evolution is slower within the first 8 hours. This behaviour can also be correlated with the kinetics of the water absorption where a lower 
absorption rate has been found for this composite as well. The explanation is that the eugenol acetate which is a hydrophobic substance was not very well distributed throughout the sample and remained predominantly near the surface of the material. In combination with higher water absorption, this caused faster release of eugenol acetate, and degradation of the filler was also more pronounced.

For sample S6 - Coll 40\%/HAp 60\%/eugenol acetate, release is slower, presumably due to slower degradation of the system, similar to the case of enzymatic degradation (Figure 2). This filler does not degrade completely in the first 24 hours as the other two samples, but the degradation lasts longer, only being complete after about 48 hours. If we associate these data with the FT-IR spectra of this sample, where a lower intensity of the bands corresponding to eugenol acetate are observed, we can suggest that it is better integrated into the system, less distributed near the surface, thus requiring the action of collagenase to degrade collagen in order to provide its release. For the sample S4-Coll/eugenol acetate sample, the release profile is growing; the concentration of eugenol acetate is increasing over time as the water absorption and collagen degradation by the enzyme take place.

\section{Conclusions}

Considering the distribution of hydroxyapatite in the polymer matrix, the assessment of the appearance and the size of the pores in the range of $100-300 \mu \mathrm{m}$ provided by SEM analysis, the presence of calcium, phosphorus and oxygen that indicates the presence of hydroxyapatite noticed from EDX analysis, the structure confirmation of the composite material based on collagen, hydroxyapatite and eugenol acetate by recording characteristic bands on FTIR, it is possible to highlight the presence of all rows materials used to obtain the specific scaffolds.

Moreover, all the data registered from kinetic release profile, water absorption and degradation capacity analysis indicate that sample Coll 70\%/HAp 30\% / eugenol acetate, release much more eugenol acetate, even if the evolution is slower within the first 8 hours. This behaviour can also be correlated with the kinetics of the water absorption capacity where it has been found a lower absorption for this composite and degradation of the system is more pronounced too. For sample Coll 40\%/HAp 60\%/eugenol acetate, release is slower, and this may be due to slower degradation of the system, as can be seen from enzymatic degradation diagram. This system does not degrade completely in the first 24 hours as the other two, but the degradation lasts longer, being complete after about 48 hours, the release capacity being longer. The reported results of physico-chemical and morphological studies of the designed composite material based on collagen, hydroxyapatite and eugenol acetate as well as the release kinetics data indicate that such formulations are promising drug delivery systems for potential applications in skeletal reconstruction after surgical intervention, e.g., tumour resection.

\section{Acknowledgement}

This paper was financially supported by "Carol Davila" University of Medicine and Pharmacy through Contract no. 23PFE/17.10.2018 funded by the Ministry of Research and Innovation within PNCDI III, Program 1 Development of the National RD system, Subprogram 1.2 - Institutional Performance - RDI excellence funding projects.

\section{Conflict of interest}

The authors declare no conflict of interest.

\section{References}

1. Munteanu D, Negru A, Mihailescu R, Tiliscan C, Tudor AM, Lazar M, Arama SS, Ion Daniela, Popescu C, Arama V, Evaluation of bone mineral density and correlations with inflammation markers in Romanian HIV-positive patients undergoing combined antiretroviral therapy. Farmacia, 2017; 65(1): 114-119.

2. Campana V, Milano G, Pagano E, Barba M, Cicione C, Salonna G, Lattanzi W, Logroscino G, Bone substitutes in orthopaedic surgery: from basic science to clinical practice. J Mater Sci Mater Med., 2014; 25(10): 2445-2461.

3. Metal Cherim RS, Erimia CL,Mustafa A, Tomescu A, Obtaining of collagen biomaterials and their use in the medical field. EJIST, 2016; 4(2): 31-38.

4. Stevens M, Biomaterials for bone tissue engineering. Materials Today., 2018; 11(5): 18-25.

5. Szczes A, Holysz L and Chibowski E, Synthesis of hydroxyapatite for biomedical applications. Adv Colloid Interface Sci., 2017; 249: 321-330.

6. Mederle N, Marin S, Marin MM, Danila E, Mederle O, Albu Kaya MG, Ghica MV, Innovative biomaterials based on collagen-hydroxyapatite and doxycycline for bone regeneration. Adv Mater Sci Eng., 2016; 2016: 1-5.

7. Ghica MV, Ficai A, Marin S, Marin M, Ene AM, Patrascu JM, Collagen/bioactive glass ceramic / doxycycline composites for bone defects. Rev Rom Matter., 2015; 45(4): 307-314.

8. Chen G, Lv Y, Dong C, Yang L, Effect of internal structure of collagen/hydroxyapatite scaffold on the osteogenic differentiation of mesenchymal stem cells. Curr Stem Cell Res Ther., 2015; 10(2): 99-108.

9. Udeanu DI, Albu Kaya MG, Ghica MV, Marin Ș, Marin MM, Kaya DA, Popa L, Dinu Pirvu CE, Antiinflammatory drug-loaded biopolymeric spongious matrices with therapeutic perspectives in burns treatment. Farmacia, 2018; 66(5): 783-790.

10. Stefanescu DC, Ceachir O, Zainea V, Hainarosie M, Pietrosanu C, Ionita IG, Hainarosie R, Methileneblue video contact endoscopyenhancingmethods. Rev Chim., 2016; 67(8): 1558-1559.

11. Hudiță A, Ioana-Lavric V, Zamfir A, Buburuzan L, Ginghină O, Negrei C, Burcea Dragomiroiu GTA, 
Costache M, Ardeleanu C, Radu E, Popa DE, Bârcă M, Iordache N, Ceaușu I, Gălățeanu B, Optimization of a flow cytometry method for the approach of liquid biopsy as a therapy modulation tool in patients with colorectal cancer. Farmacia, 2018; 66(5): 853-860.

12. Hainarosie R, Zainea V, Ceachir O, Hainarosie M, Pietrosanu C, Stefanescu DC, The use of methylene blue in early detection of the vocal fold cancer. Rev Chim., 2017; 68(1): 16-17.

13. Petrica-Matei GG, Iordache F, Hainarosie R, Bostan $\mathrm{M}$, Characterization of the tumor cells from human head and neck. Rom J Morphol Embryol., 2016; 57(2): 791-799.

14. Sajib C, Taibur R, The difficulties in cancer treatment. Ecancermedicalscience, 2012; 6: 1-5.

15. Patel NR, Pattni BS, Abouzeid AH, Torchilin VP, Nanopreparations to overcome multidrug resistance in cancer. Adv Drug Deliv Rev., 2013; 65(13-14): 1748-1762;

16. Kuskov A, Villemson AL, Shtilman M, Larionova NI, Tasatsakis AM, Tasikakas I, Rizos AK, Amphiphilic poly-N-vinylpyrrolidonenanocarriers with incorporated model proteins. J Phys Condens Matter., 2007; 19(20): 263-268.

17. Kuskov A, Kulikov P, Shtilman MI, Rakitskii VN, Tsatsakis AM, Amphiphilic poly-N-vynilpyrrolidone nanoparticles. Cytotoxicity and acute toxicity study. Food ChemToxicol., 2016; 96: 273-279.

18. Luss AL, Kulikov PP, Romme SB, Andersen CL, Pennisi CP, Docea AO, Kuskov AN, Velonia K, Mezhuev YO, Shtilman MI, Tsatsakis AM, Gurevich L, Nanosized carriers based on amphiphilic poly-Nvinyl-2-pyrrolidone for intranuclear drug delivery. Nanomedicine, 2018; 13(7): 703-715.

19. Fodor P, Fodor R, Solyom A, Catoi C, Tabaran F, Lacatus R, Trambitas C, Cordos B, Bataga T, Autologous matrix-induced chondrogenesis vs microfracture with prp for chondral lesions of the knee in a rabbit model. Rev Chimie., 2018; 69(4): 894-900.

20. Lee KG, Shibamoto T, Antioxidant property of aroma extract isolated from clove buds [Syzygiumaromaticum (L.) Merr. et Perry]. Food Chem., 20017; 4: 443-448.

21. Kuskov AN, Kulikov PP, Goyachaya AV, Tzatzarakis MN, Tsatsakis AM, Velonia K, Shtilman MI, Selfassembled amphiphilic poly-n-vinylpyrrolidone nanoparticles as carriers for hydrophobic drugs: Stability aspects. J Appl Polym Sci., 2018; 135(1): 1-12.

22. Santos AL, Chierice GO, Riga AT, Alexander K, Matthews E, Thermal behavior and structural properites of plant-derived eugenol acetate. J Therm Anal Calorim., 2009; 97: 329-332.

23. Blowman K, Magalhães M, Lemos MFL, Cabral C, Pires IM, Anticancer properties of essential oils and other natural products. Evid Based Complement Alternat Med., 2018; 2018: 1-13.

24. Sisakhtnezhad S, Heidari M, Bidmeshkipour A, Eugenol enhances proliferation and migration of mouse bone marrowderived mesenchymal stem cells in vitro. Environ Toxicol Pharmacol., 2018; 57: 166-174.

25. Sakat MS, Kilic K, Akdemir FN, Yildirim S, Eser G, Kiziltunc A, The effectiveness of eugenol against cisplatininduced ototoxicity. Braz J Otorhinolaryngol., 2018; 2018: 1-8.

26. Charles DJ, Antioxidant properties of spices, herbs and other sources. Springer New York Heidelberg Dordrecht, pp 245-253, 2012.

27. Ober C, Peștean C, Bel L, Crăciun I, Luca V, Bogdan S, Danciu C, Lăcătuș R, Purdoiu RC, Oana L, Use of ASYM $^{\circledR}$ Plates to repair diaphyseal femoral fractures in two cats. Lucrări Științifice Medicină Veterinară Iasi. 2017; 60(2): 245-249.

28. Günther S, Hempel D, Dunkel M, Rother K, Preissner $\mathrm{D}$, SuperHapten: a comprehensive database for small immunogenic compounds. Nucleic Acids Res., 2007; 35: 906-910.

29. Orsolic N, Sver L, Terzic S, Tadic Z, Tardic I, Basic inhibitory effect of water-soluble derivative of propolis and its polyphenolic compounds on tumor growth and metastasizing ability: a possible mode of antitumor action. Nutr Cancer Journal., 2003; 47: 156-163.

30. Timsina B, Nadumane VK, A review of few essential oils and their anticancer property. J Nat Pharm., 2012; 3(1): 1-9.

31. Albu MG, Collagen Gels and Matrices for Biomedical Applications; Lambert Academic Publishing: Saarbrücken, Germany, 2011.

32. Marin S, Albu Kaya MG, Ghica MV, Dinu-Pirvu C, Popa L, Udeanu DI, Mihai G, Enachescu M, Collagenpolyvinyl alcohol-indomethacin biohybrid matrices as wound dressings. Pharmaceutics., 2018; 10: 224- 241. 